DOI: https://doi.org/10.18371/fp.3(35).2019.190176

УДК 336:657.1

\title{
КОНТРОЛІНГ ФІНАНСОВИХ РИЗИКІВ СІЛЬСЬКОГОСПОДАРСЬКИХ ПІДПРИєМСТВ
}

\author{
ЯРМОЛЕНКО Віталіна Вікторівна \\ аспірант кафедри економіки та фінансів \\ ДВНЗ «Херсонський державний аграрний університет» \\ e-mail:vitalina.yarmolenko2016@gmail.com
}

Анотація. B статті розглянуто групи ризиків, які можуть виникати на сільськогосподарських підприємствах. Визначено суть контролінгу як засобу ефективного внутрішнього контролю діяльності аграрного підприсмства. Зазначено етапи розвитку контролінгу на підприємствах. Встановлено, щзо саме контролінг відіграє значну роль в системі управління підприємством, будучи одним із найсучасніших і ефективних систем керування підприємством. Обтрунтована необхідність наявності на підприємстві служби контролю, оскільки саме ияя служба $\epsilon$ відособленою системою, завдання якої полягає в динамічному процесі перетворення та інтеграиії існуючих методів обліку, аналізу, планування, контролю $і$ координачіі в єдину систему отримання, оброблення інформачії для прийняття на його основі управлінських рімень, орієнтованих на досягнення всіх завдань, що постають перед підприємством.

Ключові слова: ризик, фінансовий ризик, економічний контроль, контролінг, фінансове управління.

Постановка проблеми. Агросфера одна 3 найбільш ризикованих сфер економіки країни. На прибутковість функціонування аграрних підприємств впливають не тільки ризики, що пов'язані 3 погодними умовами чи стихійними лихами, а й фінансові ри-
Аннотация. $B$ cmaтье рассмотрень группы рисков, которые могут возникать на сельскохозяйственных предприятиях. Определена суть контроллинга средства эффективного внутреннего контроля деятельности аграрного предприятия. Указано этапь развития контроллинга на предприятиях. Установлено, что именно контроллинг играет значительную роль в системе управления предприятием, будучи одним из самых современных и эффективных систем управления предприятием. Обоснована необходимость наличия на предприятии службы контроля, поскольку именно эта служба является обособленной системой, задача которой заключается в динамическом прочессе преобразования и интеграџии существующуих методов учета, анализа, планирования, контроля и координачии в единую систему получения, обработки информачии для принятия на его основе управленческих решении , ориентированных на достижение всех задач, стоящих перед предприятием.

Ключевые слова: риск, финансовый риск, экономический контроль, контроллинг, финансовое управление.

зики. Нестабільність фінансового середовища вимагає від суб'єктів господарювання змін у підходах до виявлення та управління фінансовими ризиками в сільському господарстві. Поява нових фінансових інструментів, зміна технологій виробництва, зрос- 
тання ролі інформації у прийнятті управлінських рішень призводить до якісних та кількісних змін у ризиках, яких зазнають агропідприємства. В зв'язку 3 цим зростає необхідність концептуальних і практично значимих розробок у сфері управління фінансовими ризиками. Зміна системи управління фінансовими ризиками на основі побудови контролінгу фінансових ризиків $\epsilon$ інноваційним кроком до запровадження принципово нового рівня фінансового менеджменту на підприємствах, підвищення їх конкурентоспроможності та максимізації вартості продукції [1].

Аналіз останніх досліджень та публікацій. Більшість науковців, які займаються проблематикою контролінгу на підприємствах всіх сфер, зокрема В.П. Андрійчук, О.В. Ареф'єва, Н.Д. Бабяк, В.В. Лавренеко, C.A. Навроцький, В.С. Ніценко, O.O. Терещенко, Н.П. Шульга, Ю.П. Яковлев, А. Дайле, Н.Г. Данілочкіна, М. Дідерігз, А.М. Кармінський, T. Райхман, Х. Кюппер, Р. Манн, Д. Хан, П. Хорват підкреслюють важливість такої підсистеми фінансового контролінгу як "контролінг ризиків", однак цілісна парадигма контролінгу фінансових ризиків, як інноваційної системи методичної, консалтингової та інформаційної підтримки ризикменеджменту підприємств, у вітчизняній літературі досі відсутня. Водночас практика засвідчує важливість постійного оновлення методів та інструментів управління фінансовими ризиками підприємств.

Метою даної статті є дослідження ролі контролінгу фінансових ризиків в діяльності підприємств сільськогосподарської галузі.

Виклад основного матеріалу. Розвиток науково-технічного прогресу вивів світову економіку на межу постіндустріального суспільства, в таких умовах значно посилився вплив невизначеності на фінансово-господарську діяльність підприємств. Зміна зовнішнього та внутрішнього середовища змушує суб'єктів господарювання більш уважніше підходити до управління ризиками, підвищувати оперативність прийняття рішень та шукати нові підходи до своєчасного виявлення впливу ризиків на основні показники діяльності підприємств. Особливо гостро проблема ефективного управління ризиками стоїть перед аграрним сектором економіки.

За своєю сутністю ризик є поєднанням ймовірності та наслідків, які призведуть до настання несприятливих подій та важливим елементом підприємницької діяльності.

При здійснені комерційної діяльності, зокрема і в сільському господарстві, прийнято виділяти чотири функціональні області - виробництво, маркетинг, фінанси та персонал [2]. Це дає змогу визначити спосіб групування ризиків, в основу якого покладено функціональну область прояву ризику. Так можна виділити такі групи ризиків: виробничі, кадрові, ринкові (цінові) та фінансові.

Багато розбіжностей виникає при визначенні місця фінансового ризику, в загальній структурі бізнес-ризиків, зокрема, через відсутність єдиної думки на економічну сутність фінансового ризику. Я.І. Невмержицький розглядає фінансовий ризик, через 
призму видів діяльності підприємств, характеризуючи його як складову ризику суб'єктів господарювання, що визначає ймовірність отримання негативних фінансових результатів (передусім, збитків) у результаті здійснення сукупності господарських операцій щодо покриття потреби підприємства у капіталі для фінансування операційної та інвестиційної діяльності [2, с.531].

I.O. Бланк формулює фінансовий ризик як результат вибору власниками або менеджерами альтернативного фінансового рішення, спрямованого на досягнення бажаного цільового результату фінансової діяльності при вірогідності настання економічного збитку (фінансових втрат) через невизначеність умов його реалізації [3, c. 21-22].

3 точки зору О.О. Терещенко фінансові ризики - ризики виникнення збитків у процесі розрахунків та фінансування, у тому числі: ризики невиконання контрагентом страхувальника своїх фінансових 3обов'язань; недотримання контрагентом строків установлення та налагодження машин, устаткування, ризики втрат прибутку внаслідок перерв у виробництві; ризики структури капіталу, ризики виникнення безнадійної дебіторської заборгованості [4, с.400].

Отже, фінансовими ризиками доцільно називати ризики, які можуть виниками перед підприємствами в результаті здійснення їх господарської діяльності та загрожують йому втратою прибутку та виникненню можливості збанкрутування.

Фінансові ризики в сільському господарстві пов'язані з нагромадженням капіталу

та

фінансуванням

підприємств, отриманням, розміщенням та використанням фінансових ресурсів. Ризик у даному випадку обумовлений змінами ставок кредитування по запозиченому капіталу та розмірами акціонерного капіталу.

Фінансові ресурси прийнято поділяти на джерела формування власних і залучених засобів. В залежності від джерел отримання фінансових ресурсів виділяють такі складові фінансового ризику сільськогосподарського підприємства:

- ризик позикового капіталу, що знаходить вираз в доступності позикового капіталу і його вартості;

- ризик власного капіталу вірогідність змін у величині капіталу;

- ризик структури капіталу - структурні зрушення в співвідношенні власних і позикових засобів.

Основними причинами виникнення фінансових ризиків в аграрних підприємствах можуть бути: різкі несприятливі коливання процентних ставок, непередбачуване скорочення термінів повернення позикових коштів, недосконалість кредитних ресурсів, відсутність запасів високоліквідних активів на підприємстві.

Сьогодні ефективне управління агропідприємством вимагає створення такої інформаційної системи, яка б забезпечувала якісні, надійні та своєчасні дані для прийняття керівниками управлінських рішень. У час нестабільної економічної ситуації в країні важливим $є$ вихід 3 кризових явищ 3 мінімальними затратами. Саме це привело до підвищення ролі контролінгу як складової системи управління підприємством. Контролінг $є$ 
принципово новою концепцією в управлінні аграрним підприємством, яка здатна забезпечити підтримку внутрішнього економічного балансу підприємства й ефективного його розвивати шляхом формування об'єктивної інформації про витрати та доходи, що дає змогу приймати найбільш оптимальні управлінські рішення. Він забезпечує прогнозний результат діяльності й ефективний зворотній зв'язок, переводить управління підприємством на но- вий рівень, інтегруючи та спрямовуючи діяльність різних служб і підрозділів підприємства на досягнення найважливіших завдань [5,6].

В.Д. Зелікман визначає контролінг як систему внутрішньофірмового оперативного управління фінансовими результатами діяльності фірми, спрямована на забезпечення досягнення іiі стратегічних цілей. [7, с. 4].

Зокрема, Д. Хан визначає контролінг як одну 3 функцій первісного управлінні або однією 3 найважливіших функцій підтримки управління підприємством, яка полягає в його інформаційному забезпеченні орієнтованого на результат [8, с.111].

А. Аткінсон під контролінгом має на увазі інтегральну систему інформації щодо організації та використання ресурсів, моніторингу та вимірювання їх та сукупність заходів для покращення діяльності так, щоб повернути активи в русло їх оптимального застосування; систему надання інформації виконавчим органам для досягнення максимально позитивного результату [9, с.34].

Тому вважаємо за доцільне трактувати контролінг як саморегулюючу підсистему методів та інструментів системи управління підприємством, яка націлена на функціональну підтримку менеджменту підприємства і включає в себе інформаційне забезпечення, планування, координацію, контроль і внутрішній консалтинг.

Варто відзначити, що система інтегрованого управління сучасного зразку виникла на західних підприємствах не раптово, традиційно виділяють чотири етапи іiі розвитку (табл. 1).

Таблиця 1

Історичні етапи становлення контролінгу на підприємствах

\begin{tabular}{|c|c|c|c|c|}
\hline Етап & Роки & $\begin{array}{l}\text { Пріоритетний } \\
\text { напрямок }\end{array}$ & Методи & Основна функція \\
\hline I & $\begin{array}{lr}\text { Початок } & 50-\text { - } \\
\text { початок } & 60-\mathrm{x} \\
\text { рр. ХХ ст. }\end{array}$ & Виробництво & $\begin{array}{l}\text { Розрахунки вит- } \\
\text { рат, калькулю- } \\
\text { вання }\end{array}$ & $\begin{array}{l}\text { Реєстрація фактів госпо- } \\
\text { дарської діяльності }\end{array}$ \\
\hline II & $\begin{array}{lr}\text { Початок } & 60-\mathrm{x}- \\
\text { початок } & 70-\mathrm{x} \\
\text { рр. ХХ ст. } & \end{array}$ & $\begin{array}{l}\text { Продуктовий мар- } \\
\text { кетинг }\end{array}$ & $\begin{array}{l}\text { Рентабельність } \\
\text { окремих про- } \\
\text { дуктів }\end{array}$ & Початкова навігація \\
\hline III & $\begin{array}{lr}\text { Початок } & 70-\mathrm{x}- \\
\text { початок } & 80-\mathrm{x} \\
\text { рр. ХХ ст. }\end{array}$ & Маркетинг клієнта & $\begin{array}{ll}\text { Розвиток } & \text { iнфор- } \\
\text { маційних } & \text { техно- } \\
\text { логій } & \text { форсує } \\
\text { стратегічне пла- } & \text { нування } \\
\begin{array}{l}\text { підприємства }\end{array}\end{array}$ & Прогнозно-аналітична \\
\hline
\end{tabular}


Закінчення таблиці 1

\begin{tabular}{|c|c|c|c|c|}
\hline Етап & Роки & $\begin{array}{c}\text { Пріоритетний } \\
\text { напрямок }\end{array}$ & Методи & Основна функція \\
\hline IV & $\begin{array}{l}\text { Початок } 80-x \\
\text { pp. i до те- } \\
\text { перішнього } \\
\text { часу }\end{array}$ & $\begin{array}{l}\text { Гарантія існування } \\
\text { підприємства } \\
\text { довгостроково } \\
\text { періоді }\end{array}$ & $\begin{array}{l}\text { Операційне та } \\
\text { стратегічне пла- } \\
\text { нування в аспекті } \\
\text { створення еко- } \\
\text { номічної доданої } \\
\text { вартості }\end{array}$ & $\begin{array}{l}\text { Комплексна: координація } \\
\text { діяльності на всіх рівнях } \\
\text { управління; аналітична: } \\
\text { досягнення рентабель- } \\
\text { ності в умовах гаранто- } \\
\text { ваної ліквідності }\end{array}$ \\
\hline
\end{tabular}

Джерело: [10, с.17]

Перш за все контролінг сьогодні орієнтований на підтримку процесів прийняття рішень на базі комп'ютеризованої системи збору та обробки інформації. Він повинен забезпечити адаптацію традиційної системи планування, обліку і контролю на підприємстві до інформаційних потреб осіб, які приймають рішення. Таким чином, до функцій контролінгу відносяться створення, обробка, перевірка і подання системної управлінської інформації. Контролінг підтримує і координує процеси планування, забезпечення інформацією, контролю і адаптації. Завдання контролінгу полягає у постійному моніторингу змін зовнішнього середовища та формуванні конкретних цілей для досягнення кінцевої мети діяльності підприємства. Контролінг є компонентом управління, забезпечує його iнформацією для координації, організації та регулювання об'єктів [11].

Контролінг, як система управління економічними процесами, містить такі складові [12]:

1. Фіксація фактичного стану справ.

2. Визначення завдань підприємства. Мета повинна бути реальною і враховувати тенденції останніх періодів, тобто очікуваний розвиток має відповідати реаліям розвитку в минулому.

3. Постійне отримання та оброблення інформації $з$ метою створення потрібних умов для ухвалення рішень. Розбіжність 3 метою - це розрив між метою і фактичним перебігом справ, які варто виправляти, застосовуючи різні способи.

4. Підготовка різноманітних допоміжних засобів, потрібних для управління підприємством. На цьому етапі пошуку дуже важливо розглянути всі можливості реального досягнення мети, тобто визначити рівні досягнення у плануванні.

5. Деталізоване планування. Після огляду можливих тенденцій і заходів, які було знайдено на фазі пошуку i стимулювання, фаза планування передбачає визначення кількісних характеристик мети. Планування повинно бути реалістичним, що є передумовою досягнення заданої мети.

6. Контроль діяльності через постійне спостереження за досягненням цілей підприємства і виконанням його планів, аналіз результатів діяльності (зіставлення фактичних показників 3 очікуваними, з'ясування причин відхилення і розбіжності даних).

Огляд наукової літератури показав, що серед вчених-економістів немає 
єдиної точки зору з приводу елементів системи контролінгу (таблиця 2).

Таблиця 2

Елементи системи контролінгу

\begin{tabular}{|l|l|l|l|l|l|l|}
\hline $\begin{array}{c}\text { Автори / } \\
\text { Елементи системи } \\
\text { контролінгу }\end{array}$ & Облік & Планування & Контроль & Моніторинг & Аналіз & Оцінка \\
\hline А. Аткінсон [9] & + & & + & + & + & \\
\hline В.Д. Зелікман [7] & + & + & + & + & & \\
\hline $\begin{array}{l}\text { В.В.Прохорова } \\
{[10]}\end{array}$ & & + & + & & & + \\
\hline М.І. Сторожик [14] & + & + & + & + & + & + \\
\hline Д. Хан [8] & & + & + & & + & + \\
\hline І.І. Цигилик [15] & + & + & + & & + & \\
\hline
\end{tabular}

В рамках сучасної концепції корпоративного управління контроль ефективності всієї системи ризикменеджменту покладається на службу внутрішнього аудиту, тоді як контроль за безпосередніми діями окремих виконавців входить до компетенції департаменту фінансового контролінгу. Роль контролінгу, як підсистеми фінансового управління аграрним підприємством, полягає у підтримці та наданні допомоги керівнику. Беручи за основу дані бухгалтерського обліку, як джерело інформації, служба контролінгу вивчає явища і процеси, що відбуваються на підприємстві, виявляє слабкі місця, порівнює фактичні показники із запланованими та аналізує причини відхилення, а також пропонує заходи щодо покращення ситуації на підприємстві.

Сутність системи управління полягає у визначенні політики підприємства на перспективу, координації діяльності підрозділів, стратегічній політиці персоналу, розв'язанні основних завдань ведення бізнесу. При цьому окремі стадії управлінського процесу $\epsilon$ логічними зв'язками та утворюють комплекс управлінського циклу, який постійно повторюється і для якого характерний прямий та зворотній зв'язки.

Сучасний контролінг включає в себе управління ризиками, велику систему інформаційного постачання підприємства, систему оповіщення шляхом управління системою ключових індикаторів, управління системою реалізації стратегічного, тактичного та оперативного планування та систему менеджменту якості. Підтримуємо думку Яковенко К.В. [15], що основними причинами, які $є$ перешкодами на шляху до повноцінного впровадження контролінгу на вітчизняних аграрних підприємствах, можна виділити:

- нестабільність політичного середовища;

- нестабільність економічної політики багатьох підприємств;

- неузгодженість у діяльності різних відділів підприємств, недостатня прозорість інформації;

- ігнорування та недооцінка проблем зовнішнього середовища;

- значні витрати, пов'язані з упровадженням системи контролінгу; 
- нестача фахівців, що володіють необхідними знаннями та навичками у сфері контролінгу.

На сьогодні для всіх підприємств аграрного сектору $є$ необхідність побудови служби внутрішнього аудиту на основі орієнтації на ризик, що дає власникам дієвий інструмент контролю ефективності ризик-менеджменту. Крім того, ризико-орієнтований аудит надає додаткову інформаційну підтримку менеджменту, цим самим страхує процес контролінгу ризиків на підприємстві, використовуючи власні специфічні методики [16].

Варто пам'ятати, що контролінг орієнтований, насамперед, на майбутнє. Минуле цікавить тільки тією мірою, як воно впливає на майбутнє, сприяє кращій реалізації завдань майбутнього. Мислення категоріями взаємозв'язку минулого 3 майбутнім допомагає через аналіз відхилень та їхніх причин нагромаджувати знання для пошуку оптимальних контрзаходів. У традиційному розумінні зворотній зв'язок і аналіз відхилень означають зви- чайне зіставлення того, що $\epsilon, 3$ тим, що передбачалося, тобто 3 прогнозними оцінками. Такий підхід дає змогу вчитися на минулих помилках, шукати ре- альні причини відхилень, які мали місце. Існує певна суперечність між тим, що контролінг, який будується на врахуванні операцій у минулому, використовується як інструмент, спрямований на виявлення "вузьких місць" у майбутньому зовнішньому середовищі [6].

Висновки. Отже, контролінг відіграє дуже важливу роль в системі управління ризиками сільськогосподарських підприємств, будучи одним iз найсучасніших і ефективних систем керування підприємством, $є$ відособленою системою, економічна сутність якої полягає в динамічному процесі перетворення та інтеграції існуючих методів обліку, аналізу, планування, контролю і координації в єдину систему отримання, оброблення інформації для прийняття на iï основі управлінських рішень, а точніше в систему управління підприємством, орієнтовану на досягнення всіх завдань, що постають перед підприємством.

\section{Список використаної літератури}

1. Танклевська Н.С. Основні аспекти страхування врожаїв суб'єктами АПК Південного регіону. Таврійський науковий вісник. 2007. Вип. 48. С. 168-175.

2. Фінансовий менеджмент: підручник / кер. кол. авт. і наук. ред. проф. А. М. Поддєрьогін. К.: КНЕУ, 2005. 535 с.

3. Бланк I.О. Управління фінансовими ризиками. Київ: Ніка-Центр, 2005. $600 \mathrm{c}$.

4. Терещенко О.О., Бабяк Н.Д. Фінансовий контролінг: навч. посібник. КНЕУ, $2013.407 \mathrm{c}$. 
5. Танклевська Н.С. Фінансова політика сталого розвитку аграрних підприємств України: теорія, методологія, практика: Монографія. Херсон: Айлант, 2010. 376 c.

6. Воляник Г.М., Марушко Н.С. Контролінг у системі управління підприємством. Науковий вісник НЛТУ Украйни. 2009. Вип. 19.4. с. 151-155.

7. Зелікман В.Д. Контролінг : конспект лекцій. Дніпропетровськ : НМетАУ, $2008.45 \mathrm{c}$.

8. Хан Д. Планирование и контроль:концепция контроллинга: пер. с нем. М. : Финансы и статистика, 1997. 800 с.

9. Atkinson A.A. Management Accounting. N.J. : Prentice Hall, Upper Saddle River, 1997. p. 34.

10. Прохорова В.В., Мартюшева Л.С., Петрусевич Н.Ю., Прохорова Ю. В. Контролінг - від теорії до реалізації на практиці: монографія. Х.: ВД "ІНЖЕК", 2006. $200 \mathrm{c}$.

11. Замятіна Н.В. Місце контролінгу в системі управління сучасним підприємством. Економіка і суспільство. Мукачівський державний університет. Вип.7. 2016. c. 324 - 328. URL: http://economyandsociety.in.ua/journal/7_ukr/55.pdf

12. Деменіна O.M. Ретроспективний та перспективний аспект концепцій контролінгу. Маркетинг в Украӥні. 2012. № 4(14). 55-58 с.

13. Сторожик М.І., Голубятнікова Н.В. Контролінг. Львів: ЛРІДУ НАДУ, 2004. 212c.

14. Цигилик I.I. Контролінг (навчальний посібник у схемах і таблицях). К.: Центр навчальної літератури, 2004. 76 с.

15. Яковенко К.В. Контролінг як невід'ємна складова управління сучасним підприємством. Конкурентоспроможність та інновації: проблеми науки та практики. №3. 2017. с.261-264.

16. Танклевська Н.С. Вдосконалення механізму страхування діяльності аграрних підприємств. Науковий вісник НАУ. 2008. Вип. 118. С.320-325. 